\title{
p38 mitogen-activated protein kinases: their role in carcinogenesis
}

\author{
Victoria Sanz-Moreno and Piero Crespo \\ Instituto de Investigaciones Biomédicas. Consejo Superior de Investigaciones Científicas. Unidad Asociada a la Unidad de \\ Biomedicina de la Universidad de Cantabria. Departamento de Biología Molecular. Facultad de Medicina. Cantabria.
}

The members of the p38 subfamily of Mitogen-Activated Protein Kinases (MAPKs) are a versatile group of proteins, that function as signal transducers involved in key cellular functions. Initially, p38 MAPKs were associated with inflammatory and cellular stress responses and, as such, p38 has been an important target for anti-inflammatory therapies. Recently, increasing evidence has directly implicated p38 MAPKs in processes essential for cell development, transformation and tumorogenesis, namely: proliferation, differentiation, apoptosis, invasion and metastasis. These features make p38 MAPKs potential targets for future anti-neoplastic therapies.

Key words: p38, MAP kinases, serine-threonine kinases, carcinogenesis, transformation.

Sanz Moreno V, Crespo P. p38 mitogen-activated protein kinases: their role in carcinogenesis. Rev Oncol 2003;5(6):32030.

\section{Participación de MAP quinasas p38 en carcinogénesis}

Los componentes de la subfamilia p38 de quinasas activadas por mitógenos (MAP quinasas) constituyen un grupo de proteínas muy versátiles, que actúan como transductoras de señales en funciones celulares de capital importancia. Originalmente las proteínas $\mathrm{p} 38$ han sido asociadas con respuestas inflamatorias y de estrés celular, debido a lo cual p38 se ha convertido en una diana terapéutica de especial relevancia en el control de enfermedades asociadas a estos procesos.

No obstante, actualmente existen evidencias considerables para también implicar directamente a p38 en eventos de capital importancia dentro de la transformación celular y la tumorogénesis, en concreto: proliferación, diferenciación, apoptosis, invasión y metástasis. Estas propiedades de las MAP quinasas p38 las convierten en potenciales dianas para futuras terapias antineoplásicas.

Palabras clave: p38, MAP quinasas, serina-threonina quinasas, carcinogénesis, transformación.

\begin{abstract}
Mitogen-activated protein kinases (MAPKs) are cytoplasmic serine/threonine kinases that are activated in response to a wide array of extracellular stimuli, including those that regulate cell proliferation, differentiation, development and inflammation. MAPKs are pivotal elements in the transduction of signals from the membrane to the interior of the cell, acting as essential mediators in signalling modules that include sequentially: MAP kinase kinase kinases (MAPKKKs), dual-specificity MAP kinase kinases (MAPKKs) and MAPKs. To date, four mammalian MAPKs families have been studied in detail: ERKs (extracellular signal
\end{abstract}

Correspondence: Dr. Piero Crespo.

Instituto de Investigaciones Biomédicas.

Consejo Superior de Investigaciones Científicas.

Unidad de Biomedicina de la Universidad de Cantabria.

Departamento de Biología Molecular.

Facultad de Medicina.

C/ Cardenal Herrera Oria, s/n

39011 Santander.

E-mail: pcrespo@iib.uam.es

Received 2 June 2003; Accepted 23 June 2003. regulated kinases), JNK/SAPKs (c-jun N-terminal kinase/stress activated protein kinases), ERK5/BMKs (Big MAP kinases) and p38 MAPKs ${ }^{1,2}$. Even though the activation of the different MAPKs was originally associated to defined types of stimuli, it is now clear that most stimuli can switch on several MAPK modules and that the biological outcomes of such stimuli are consequences of the integration of the intensity and duration of the signals transduced by each individual MAPK route. The biological mechanisms involved in cellular transformation and oncogenesis are no exception and, to date, all MAPKs have been found to be involved, one way or another, in distinct aspect of carcinogenesis. This review will focus in the role played by p38 MAPKs in those processes that turn awry at some stage of the malignification process.

\section{THE p38 MAPK FAMILY}

p38 $\alpha /$ CSBP2/RK2 was first identified as an endotoxin-stimulated kinase ${ }^{3}$. At the same time, a target for imidazole anti-inflammatory drugs was identified, 
TABLE 1. Main features of p38 family members

\begin{tabular}{|c|c|c|c|c|c|c|c|}
\hline Member & Identification & $\begin{array}{l}\text { Splicing } \\
\text { isoforms }\end{array}$ & $\begin{array}{l}\text { Tisular } \\
\text { distribution }\end{array}$ & $\begin{array}{l}\text { Imidazole } \\
\text { response }\end{array}$ & $\begin{array}{l}\text { Activating } \\
\text { stimuli }\end{array}$ & Substrates & Special features \\
\hline $\begin{array}{l}\text { p38 } \alpha \\
\text { CSBP2 } \\
\text { RK2 }\end{array}$ & $\begin{array}{l}\text { CSBP2 had great } \\
\text { homology with yeast } \\
\text { protein HOG. It was } \\
\text { identified by several } \\
\text { approaches }{ }^{4}\end{array}$ & $\begin{array}{l}\text { A } 25 \text { residue internal } \\
\text { sequence makes } \\
\text { CSBP1 different from } \\
\text { CSBP2. CSBP1 } \\
\text { complements HOG } 1 \\
\text { deletion in yeast. } \\
\text { Mxi2 }{ }^{12} \text { and Exip }{ }^{13} \\
\text { are two other }^{\text {alternative splicing }} \\
\text { products }\end{array}$ & $\begin{array}{l}\text { p38 } \alpha \text { is } \\
\text { ubiquitous and } \\
\text { the rest of the } \\
\text { isoforms present } \\
\text { a more restricted } \\
\text { pattern of } \\
\text { expression. Mxi2 } \\
\text { appears to be } \\
\text { only expressed } \\
\text { in kidney }{ }^{24}\end{array}$ & $\begin{array}{l}\text { CSPB2 activity } \\
\text { is inhibited by } \\
\text { imidazoles, but } \\
\text { Mxi2 isn't }{ }^{25}\end{array}$ & $\begin{array}{l}\text { This kinase is } \\
\text { activated by } \\
\text { IL-1 } 1 \beta \text {, TNF- } \alpha \text {, } \\
\text { sorbitol (osmotic } \\
\text { shock) or UV } \\
\text { radiation. } \\
\text { Both MKK3 and } \\
\text { MKK6 can } \\
\text { activate it }{ }^{2}\end{array}$ & $\begin{array}{l}\text { It phosphorylates } \\
\text { MBP, ATF-2, } \\
\text { MAPKAP-K2, } \\
\text { MAPKAP-K3, MNK, } \\
\text { MSK, CHOP, PRAK, } \\
\text { MEF2C and Max, } \\
\text { but not C-Jun, as the } \\
\text { rest of p38 family } \\
\text { members. Sap-1a y } \\
\text { Elk-1 are also good } \\
\text { substrates }^{16-23}\end{array}$ & $\begin{array}{l}\text { CSBP2 is the most } \\
\text { abundant isoform } \\
\text { of the family and } \\
\text { has been more } \\
\text { extensively studied }\end{array}$ \\
\hline p38 $\beta$ & $\begin{array}{l}\text { In } 1996 \text { Jiang et al } \\
\text { described the } \\
\text { cloning and } \\
\text { characterization of } \\
\text { this family member } \\
\text { with } 74 \% \text { homology } \\
\text { with p38 } \alpha\end{array}$ & $\begin{array}{l}\text { Kumar et al tried to } \\
\text { clone p38 } \beta \text { by RT- } \\
\text { PCR using Jiang et } \\
\text { al sequence, but the } \\
\text { cDNA obtained had } \\
\text { an internal delection } \\
\text { of } 8 \alpha \alpha, \text { which they } \\
\text { named p38 } \beta 2^{7}\end{array}$ & $\begin{array}{l}\text { Similar pattern of } \\
\text { distribution as } \\
\text { p38 } \alpha \text {, being } \\
\text { expressed in } \\
\text { kidney, pancreas, } \\
\text { muscle, spleen, } \\
\text { lung, placenta, } \\
\text { heart and brain }\end{array}$ & $\begin{array}{l}\text { It's kinase } \\
\text { activity is } \\
\text { inhibited by } \\
\text { imidazole } \\
\text { compounds } 5\end{array}$ & $\begin{array}{l}\text { It is activated by } \\
\text { the same kind of } \\
\text { stimuli as p38 } \alpha \text {, } \\
\text { showing a slower } \\
\text { activation kinetics. } \\
\text { It is not activated } \\
\text { by phorbol esters. } \\
\text { MKK } 6 \text { can } \\
\text { activate it } \\
\text { although MKK3 } \\
\text { cannot }^{5}\end{array}$ & $\begin{array}{l}\text { MBP, ATF-2, } \\
\text { MAPKAP-Kinase 2, } \\
\text { MAPKAP-Kinase } 3 \\
\text { are good substrates, } \\
\text { but not C-Jun } 7\end{array}$ & $\begin{array}{l}\text { The extra and } \\
\text { unique } 8 \alpha \alpha \text { p38 } \\
\text { are an insertion } \\
\text { when comparing } \\
\text { with the rest of } \\
\text { MAPKs, so p38 } \beta 2 \\
\text { has more } \\
\text { correlated } \\
\text { sequence when } \\
\text { compared with the } \\
\text { other family } \\
\text { members }\end{array}$ \\
\hline p382 & $\begin{array}{l}\text { In } 1997, \text { Stein et al } \\
\text { described a new } \\
\text { isoform, p382, } \\
\text { identical to p38 } \beta \\
\text { except in } 3 \\
\text { aminoacids }^{14}\end{array}$ & $\begin{array}{l}\text { This isoform was } \\
\text { isolated in three } \\
\text { different forms, two } \\
\text { of them have no } \\
\text { phosphorylation } \\
\text { motif }\end{array}$ & $\begin{array}{l}\text { It's expression } \\
\text { pattern differs } \\
\text { from p38 } \alpha \text {, being } \\
\text { most abundant in } \\
\text { heart and testes } \\
\text { and less } \\
\text { abundant in } \\
\text { placenta and } \\
\text { ovaries }^{14}\end{array}$ & $\begin{array}{l}\text { It's activity can } \\
\text { be inhibited by } \\
\text { imidazoles as } \\
\text { much as p38 } \alpha\end{array}$ & $\begin{array}{l}\text { Stein et al showed } \\
\text { that anisomycin, } \\
\text { UV and sorbitol } \\
\text { activated this } \\
\text { kinase. MKK } 6 \text { is } \\
\text { also a good } \\
\text { activator. }\end{array}$ & $\begin{array}{l}\text { It can phosphorylate } \\
\text { ATF-2, Elk-1 and } \\
\text { Sap-1a. }\end{array}$ & $\begin{array}{l}\text { It's remarkable } \\
\text { that ATF-2 is } 180 \\
\text { times better } \\
\text { substrate for p382 } \\
\text { than for p38 } \alpha^{14}\end{array}$ \\
\hline $\begin{array}{l}\text { p38 } \gamma \\
\text { SAPK4 }\end{array}$ & $\begin{array}{l}\text { Han et al described } \\
\text { this kinase in } 1996 \\
\text { after identifying it in } \\
\text { Gen Bank. It's } 63 \% \\
\text { homologous to p38 } \alpha \\
\text { and } 62 \% \text { to p38 } \beta\end{array}$ & $\begin{array}{l}\text { Not described } \\
\text { so far }\end{array}$ & $\begin{array}{l}\text { mRNA of this } \\
\text { isoform is just } \\
\text { found in skeletal } \\
\text { muscle, which } \\
\text { suggests a } \\
\text { specific function } \\
\text { in this tissue }\end{array}$ & $\begin{array}{l}\text { Kumar et al } \\
\text { found that this } \\
\text { kinase cannot be } \\
\text { inhibited by } \\
\text { imidazoles, due } \\
\text { to mutations in } \\
\text { aminoacids } 106 \text {, } \\
107 \text { and } 108 \text { with } \\
\text { respect to p38 } \alpha^{7}\end{array}$ & $\begin{array}{l}\text { It's activated by } \\
\text { typical stress } \\
\text { stimuli, such as IL- } \\
1, \text { TNF- } \alpha \text {, sorbitol, } \\
\text { UV and it is also } \\
\text { activated by PMA. } \\
\text { It's not regulated } \\
\text { by insulin, serum } \\
\text { and okadaic acid } \\
\text { and it is activated } \\
\text { by ortovanadate }{ }^{7}\end{array}$ & $\begin{array}{l}\text { It can phosphorylate } \\
\text { ATF- } 2 \text {, and } \\
\text { MAPKAP K3, but it } \\
\text { is unable to } \\
\text { phosphorylate } \\
\text { MAPKAP K } 2^{10}\end{array}$ & $\begin{array}{l}\text { Lechner et al } \\
\text { showed that this } \\
\text { isoform works as a } \\
\text { signal transducer } \\
\text { during } \\
\text { differentiation from } \\
\text { myoblasts to } \\
\text { myotubes in } \\
\text { C2C12 cells. This } \\
\text { kinase favours } \\
\text { nuclear myotubular } \\
\text { fusion rate, which is } \\
\text { a sign of } \\
\text { differentiation } 26\end{array}$ \\
\hline $\begin{array}{l}\text { p388 } \\
\text { ERK6 }\end{array}$ & $\begin{array}{l}\text { In } 1997 \text {, Jiang et al } \\
\text { cloned and } \\
\text { characterized this } \\
\text { member. This } \\
\text { isoform is } 60 \% \\
\text { homologous to } \\
\text { p38 } \alpha^{6}\end{array}$ & $\begin{array}{l}\text { They haven't been } \\
\text { described }\end{array}$ & $\begin{array}{l}\text { The study of its } \\
\text { mRNA revealed } \\
\text { a higher } \\
\text { expression in } \\
\text { kidney and lung } 6\end{array}$ & $\begin{array}{l}\text { Kumar et al } \\
\text { showed that this } \\
\text { kinase is not } \\
\text { inhibited by } \\
\text { imidazoles }\end{array}$ & $\begin{array}{l}\text { It's activated by: } \\
\text { anisomycin, PMA, } \\
\text { arsenite, PAF, } \\
\text { oxidative stress, } \\
\text { TNF- } \alpha, \text { IL-1,IL-6 } \\
\text { and UV. Neither } \\
\text { serum, insulin, or } \\
\text { EGF have any } \\
\text { effect on its } \\
\text { activity }{ }^{6}\end{array}$ & $\begin{array}{l}\text { It can phosphory- } \\
\text { late MBP, ATF-2, } \\
\text { Elk-1 and MAPKAP } \\
\text { K } 3 \text {, } \\
\text { but not } \\
\text { MAPKAPK } 2^{6}\end{array}$ & $\begin{array}{l}\text { It seems that p38 } \\
\text { and p38 } \delta \text { have } \\
\text { evolved towards a } \\
\text { different subclass } \\
\text { of p38 MAPK which } \\
\text { differ from p38 } \alpha \\
\text { and from p38 } \beta \text {, } \\
\text { having a more } \\
\text { restricted tisular } \\
\text { distribution, } \\
\text { Greater } \\
\text { susceptibility to } \\
\text { PMA, A different } \\
\text { substrate } \\
\text { specificity, and a } \\
\text { different sensibility } \\
\text { to imidazoles }{ }^{6} \text {. }\end{array}$ \\
\hline
\end{tabular}


that actually turned up to be p38 $\alpha^{4}$. Since then, other three p38 isoforms have been described: p38, $\beta$, $\gamma /$ SAPK 4 , and $\delta / E R K 6^{5-10}$. Also, splicing variants of p38 $\alpha$ and p38 $\beta$, namely CSBP1, Mxi2, Exip ${ }^{11-13}$, p38-2 and $\mathrm{p} 38 \beta 2$ have been reported ${ }^{7,14}$.

p38 MAPKs are substrates for the dual-specificity kinases MKK3 and MKK6 and to a lesser extent for MKK4. Likewise, p38 MAPKs are activated by an ever-growing number of upstream MAPKKKs and MAPKKKKs ${ }^{2}$. Also, in a fashion similar to SAPK/JNKs, the cascade that leads to p38 activation is regulated at its origins by Rho family GTPases ${ }^{1}$.

Once activated, p38 MAPKs can phosphorylate a number of cytoplasmic proteins like cPLA2 ${ }^{15}$ and kinases like MAPKAPK $2 / 3^{16}$ MSK $^{17}$, MNK $^{18}$ and PRAK $^{19}$. In addition, p38 MAPKs translocate to the nucleus where they phosphorylate a broad range of transcription factors like those of the Ets ${ }^{20}, \mathrm{ATF}^{21}$, $\mathrm{MEF}^{22}$ and $\mathrm{GADD}^{23}$ families among others. The activation of these downstream mediators sets in motion the cellular processes and genetic programs ultimately responsible for the biological outputs regulated by $\mathrm{p} 38$ MAPKs. The main features of p38 isoforms are summarized in table 1.

\section{p38 MAPKS AND CANCER}

Even though p38 MAPKs cannot be considered oncogenes sensu stricto, as they cannot induce cellular transformation, mounting evidence associate the activation of the $\mathrm{p} 38$ pathway to many aspects of carcinogenesis. With respect to MAPKs, oncogenic transformation and tumour progression has been traditionally linked to the aberrant function of the Ras/ERK pathway $^{27}$. However, it is becoming clear that JNK and p38 MAPKs also play an important role in transformation under some circumstances. A clear case is exemplified by the oncogene mas encoding for a $\mathrm{G}$ protein-coupled receptor that induces transformation mediated by the activation of the $\mathrm{JNK} / \mathrm{p} 38$ cascades but with no concomitant activation of $\mathrm{ERK}^{28}$. Another example is the herpes virus associated to Kaposi's Sarcoma HHV8, that also expresses a G-coupled receptor capable of activating both JNK and p38 and provokes cellular transformation and activates angiogenesis $^{29}$.

Constitutive activation of the p38 pathway can be detected in different types of tumours. Some studies reported high levels of p38 (p38 refers to p38 $\alpha$ hereafter, unless otherwise indicated) kinase activity in non-small cell lung carcinomas ${ }^{30}$. In human breast tumours analyzed for the expression of p21-activated kinase (PAK), p38 and MAPKAPK-2, all these proteins were overexpressed and exhibited increased activity ${ }^{31}$. Activation of p38 was significantly elevated in welldifferentiated prostatic tumours. Furthermore, prostatic intraepithelial neoplastic lesions exhibiting activa- ted p38, were observed to be proliferative rather than apoptotic $^{32}$. p38 also appears to be determinant for the progression of multiple myelomas ${ }^{33}$. Also, in a cell culture model of ovarian epithelium, activation of signalling proteins, particularly those of the MEK6/p38/ MAPKAPK-2 pathway and the PI3K pathway, were found to correlate with phenotypic manifestations of progressive stages in the development of ovarian cancer $^{34}$. All these cases clearly associate p38 to malignancies. Something that should come as no surprise, as in these past years evidence has mounted relating p38 activation to many essential processes in the upbringing of cellular transformation and tumoral progression.

\section{p38 IN APOPTOSIS/CELL SURVIVAL}

Apoptosis is one of the main safeguards against uncontrolled cell proliferation, by getting rid of those cells that are no longer useful. Apoptosis can be promoted by multiple intra and extracellular signals such as DNA damage, deprivation of growth factors or activation of death receptors ${ }^{35}$. p38 activation has been associated to apoptosis caused by diverse stimuli in many cellular models ${ }^{27}$. In diverse cell types, overexpression of upstream components of the p38 cascade is sufficient to induce apoptosis. Fibroblasts transfected with activated MEKK1 die by apoptosis ${ }^{36}$ and $\mathrm{T}$ cells expressing activated Cdc42 have increased JNK/p38 activation and undergo apoptosis due to augmented caspase activity ${ }^{37}$. ASK1 (apoptosis signal kinase1) can activate p38 direct activators MKK4 and MKK3/6 and when overexpressed, is a potent inductor of cell death ${ }^{38}$.

In these cases apoptosis induction required massive activation of $\mathrm{p} 38$, that may not be reminiscent of a physiological situation. However, a large body of evidence indicates that, at physiological levels, most apoptogenic stimuli are accompanied by p38 activation. Ceramide mediates in apoptosis induction responding to diverse stimuli including TNF, TGF and Fas-Ligand $^{27}$. p38 activation seems to be a key event in this process since chemical inhibitors for p38 block apoptosis induced by ceramides ${ }^{39}$. Apoptosis induced by heat shock is also associated with JNK/p38 activation. High levels of heat shock protein Hsp70, protects against cell death, partly by inhibiting JNK/p38 activation $^{40}$.

On the other hand, anti apoptotic stimuli and agents tend to prevent p38 activation. Insulin has neuroprotective effects in foetal neurons. In these cells, insulin specifically inhibits p38 activity ${ }^{41}$. In a similar fashion, UV light-induced apoptosis can be blocked by the expression of the dual specificity phosphatase MKP-1 which decreases JNK/p38 activation ${ }^{42}$. Suppression of serum deprivation-induced apoptosis in NIH3T3 by TGF- $\beta$ is also exerted through the inhibition of $p 38^{43}$. 
Likewise, expression of dominant negative MKK3 blocks cisplatin-induced apoptosis ${ }^{44}$.

Although p38 was initially described as an apoptosisinducing kinase $\mathrm{e}^{38}$, recent evidence show that depending on the cell type and the apoptogenic stimuli, p38 can act, not only as positive regulator of cell death, but also as a negative one. On one hand, in PC12 cells, p38 activation favours NGF deprivation-induced apoptosis ${ }^{45}$. On other cell types like cardiomyocytes, p38 activation can protect from apoptosis induced by anisomycin $^{46}$. Likewise, in endothelial cells where TNF- $\alpha$ produces inflammation rather than apoptosis, TNF stimulates p38 with bimodal kinetics, interruption of early p38 activation can enhance TNF- $\alpha$-induced apoptosis, suggesting a protective role for $\mathrm{p} 38^{47}$. Moreover, the activation of the p38 substrate MEF2C, is necessary for neuron survival, unveiling a direct link between survival and p38 activation ${ }^{48}$. Adding more complexity to the regulation of pro and anti apoptotic functions by p38 family members, there are some studies that provide evidence for differences between p38 isoforms when regulating apoptotic processes. In cardiomyocytes and Hela cells, p38 $\alpha$ induces apoptosis while p38 $\beta$ promotes cell survival ${ }^{49}$. Furthermore, p38 $\beta$ but not p38 $\alpha$ can protect mesangial cells from TNF $\alpha$-induced apoptosis ${ }^{50 .}$

Currently, the prevailing line of thought is that, rather than the activation of a single, discrete route, what ultimately determines whether a cell survives or undergoes apoptosis is the dynamic balance between survival and stress signals. The first evidences on this respect, were provided by $\mathrm{Xia}$ et al, that found that in PC12 cells the induction of apoptosis depended on the relative contributions of JNK/p38 and ERK activities. In these cells, apoptosis caused by NGF withdrawal was accompanied by a sustained activation of JNK/p38 and the inhibition of ERK ${ }^{51}$. A similar case was observed in sympathetic neurons overexpressing MEKK1. Once again, tilting the balance of relative activities towards p38/JNK in comparison to ERKs, resulted in apoptosis $^{51}$. On the other hand, transient activation of ERK induced by EGF stimulated proliferation, whereas prolonged ERK activation by NGF induced neuronal differentiation, in both cases JNK/p38 activity levels were $l o w^{52,53}$. An analogous situation was observed in the case of constitutively active ASK1, which potentiates apoptosis in NGF-differentiated PC12 cells and rat sympathetic neurons, while a dominant negative ASK1 reduces apoptosis. However, in undifferentiated PC12 cells, moderate expression of ASK1 induces neural differentiation through the activation of $\mathrm{p} 38^{54,55}$. These results suggest that a strong activation of ASK-p38 pathway leads to apoptosis, whereas a milder activation would lead to differentiation. These situations also illustrate that the (relative) activation intensity of a MAPK route is not the sole factor in the decision of cell fate. In addition, the du- ration of the signal is also determinant. As such, in PC12 cells, early/transient and late/sustained activation of JNK/p38 induced by TNF- $\alpha$ have been reported to correlate with survival/differentiation or with apoptosis, respectively ${ }^{56,57}$.

This interplay among survival pathways, like ERK, and pro-apoptotic pathways such as p38, is highlighted by many anti tumoral drugs, whose mode of action is the induction of apoptosis in the targeted cells. As such, flavopiridol induces apoptosis in chronic lymphocytic leukaemia B-cells by activating p38 and suppressing ERK activity ${ }^{58}$. An identical situation is observed in leukemic U937 cells induced to undergo apoptosis by arsenic trioxide ${ }^{59}$. Lastly, taxol ability to induce apoptosis in different cell types is intimately dependent on its capacity to activate p38 and suppress ERK ${ }^{60,61}$.

One important question is: how does p38 activation set in motion the machinery responsible for executing apoptosis? Even though this issue remains largely unanswered, the emerging picture, somewhat expected, is that there is not a single culprit. As such in renal cells, p38 mediates cell growth arrest and apoptosis through the transactivation of GADD45 and GADD153 (Growth Arrest and DNA Damage inducible gene) ${ }^{62}$. In response to UV light, p38 stimulates the transcriptional activity of $\mathrm{p} 53^{63}, \mathrm{p} 38$ also regulates the activation of p53 in response to genotoxic stress and inhibition of p38 reduces p53-mediated apoptosis induced by chemotherapeutic agents ${ }^{64}$. In chondrocytes, nitric oxide-induced apoptosis is dependent on p38 activation, that induces the accumulation of p53 via NF- $\mathrm{kB}-\mathrm{de}-$ pendent transcription and its stabilization by direct phosphorylation ${ }^{65}$. A similar situation is observed in UV-induced apoptosis in keratinocytes ${ }^{66}$. An inhibitor of cell cycle progression, the p53-inducible phosphatase Wip1 mediates a negative feedback regulation on p38 signalling in response to UV, by dephosphorylating p38 $8^{67}$. Inactivation of $\mathrm{p} 38$ by Wip-1 facilitates tumour formation ${ }^{68}$. Accordingly, there are recent reports showing that Wip1 is overexpressed in breast tumours ${ }^{69}$. Other mechanisms are also known to intervene in p38-mediated apoptosis: ASK1 was reported to execute apoptosis mainly by mitochondria-dependent caspase activation ${ }^{70}$. In this context, a large body of data suggests that p38 activation results in cytochrome C release from mitochondria and subsequent activation of caspases 3 and $8^{71,72}$, that can be specifically blocked by p38 pharmacological inhibitors ${ }^{73-76}$. In light of all these data it becomes evident how by altering p38 activation status some cells may subvert pro-apoptotic mechanisms as a route to immortalization and tumoral growth.

\section{p38 MAPKS IN DIFFERENTIATION}

It is well established that apoptosis, proliferation and differentiation are intimately linked processes gover- 
ned by common mechanisms. As such, growing evidence also involve p38 in differentiation processes in various cellular systems:

1) Adipocytic differentiation. In 3T3 L1 fibroblasts adipocytic differentiation induced by insulin was blocked by p38 inhibitory mutants or by the p38 specific inhibitor SB203580. Conversely, expression of a constitutively active mutant of MKK6 induced adipocytic differentiation ${ }^{77}$. The transcription factors CCAAT/enhancer-binding protein $\beta(\mathrm{C} / \mathrm{EBP} \beta)$ and peroxisome proliferator-activated receptor (PPAR $\gamma$ ) might be the likely p38 targets during adipogenesis. p38 inhibitors strongly reduce the expression of PPAR $\gamma$ and the amount of C/EBP $\beta^{78}$. Furthermore, it has been demonstrated that p38 inhibitors block the differentiation of mesenchymal C3H10T1/2 cells into adipocytes induced by bone morphogenetic protein 2 (BMP2), essentially by preventing the transcriptional activation of PPAR $\gamma^{79}$.

2) Myogenic differentiation. In $\mathrm{C} 2 \mathrm{C} 12$ cells, deprivation of growth factors results in myogenic differentiation, that correlates with elevated p38 activity ${ }^{80}$. Moreover, treatment with SB203580 retards myoblast elongation and alignment, prevents myoblast fusion to form multinucleated myotubules, and inhibits the expression of muscle-specific genes. p38 regulates MyoD, a transcriptional activator essential for myogenesis, by two mechanisms: augmenting its levels by increasing its transcription, regulated by the p38 substrate MEF2C, and by increasing its stability through direct phosphorylation ${ }^{81}$. It has also been described how activation of p38 induces cell cycle arrest via the inhibition of Raf/ERK pathway during muscle differentiation in myoblasts, by as yet unknown mechanisms $^{82}$.

3) Cardiac hypertrophy is an adaptative response of the heart to a variety of intrinsic and extrinsic stimuli. The hypertrophic response, during which cardiomyocytes increase in size without undergoing cell division, initially serves to compensate for decreased cardiac output; however, prolonged hypertrophy can become detrimental, resulting in dilated cardiomyopathy and heart failure ${ }^{91}$. p38 activity was significantly increased in mouse hearts after chronic aortic constriction, coincident with the onset of ventricular hypertrophy ${ }^{92}$. Infection of cardiomyocytes with adenovirures expressing, MKK3 and MKK6 elicited characteristic hypertrophic responses, including an increase in cell size, enhanced sarcomeric organization, and elevated atrial natriuretic factor (ANF) expression. The direct involvement of p38 in cardiac hypertrophy suggests a significant role for p38 in the pathophysiology of heart failure.

4) Neuronal differentiation. Treatment of PC12 cells with SB203580 or transfection with p38/MKK6 inhibitory mutants originate a profound inhibition of NGF-induced neurite outgrowth ${ }^{83}$. Conversely, pre- vious reports had suggested that sustained activation of the ERK pathway was sufficient for PC12 differentiation. This was based on the induction of differentiation, in the absence of NGF, by expression of a constitutively active mutant of MEK ${ }^{84}$. It now appears that expression of constitutively active MEK1 can also activate p38 and that SB203580 can block MEK1induced neurite outgrowth, even though ERK would still be active. However, sustained activation of p38 is not very efficient for inducing neurite outgrowth in PC12 cells, except when combined with EGF stimulation, which induces transient activation of both ERK and p38. Based on these results, it has been proposed that neuronal differentiation of PC12 cells might require a sustained activation of either ERK or p38 MAPKs, combined with the transient activation of the other MAPK ${ }^{85}$.

5) Osteogenic differentiation. p38 plays an important role in osteoblast differentiation in several cell systems. p38 and ERK are activated as calvarial osteoblast differentiate into mature osteocytes. When p38 was inhibited with pyridinil imidazoles, the expression of differentiation markers, such as alkaline phosphatase (ALP) and mineral deposition, were significantly reduced. MC3T3-E1 osteoblastic cells expressing dominant negative p38 also displayed a delayed mineral deposition and reduced ALP activity. Finally, differentiation of bone marrow osteoprecursors was also impeded by the p38 MAPK inhibitor, as justified by the same markers of osteogenic differentiation $^{86}$.

6) Chondrogenic differentiation. ATDC5 cells are differentiated by Growth/Differentiation factor-5 (GDF-5) that induces a potent activation of p38 and ERK. Phosphorylation of p38 was also induced by BMP-2 and TGF- $\beta 1$. An inhibitor of p38 $\alpha$ and $\mathrm{p} 38 \beta$, SB202190, caused complete inhibition of cartilage nodule formation induced by GDF-5, but failed to affect ALP activity. Expression of the type II collagen, a hallmark of chondrogenesis, was also induced by GDF-5 and strongly suppressed by SB202190. On the other hand, although the inhibitor of ERK, PD98059, blocked the phosphorylation of ERK by GDF-5, it inhibited neither ALP activity nor cartilage nodule formation ${ }^{87}$. Treatment of chicken mesenchymal cells with cytochalasin D disrupted the actin cytoskeleton with concomitant chondrogenic differentiation ${ }^{88}$. The chondrogenic process was accompanied by an increase in p38 activity and inhibition of p38 with SB203580 blocked this process ${ }^{88}$.

7) Erythroid differentiation. Erythroid differentiation of K562 cells induced by cyclosporin A ${ }^{89}$, and of SKT6 cells induced by erythropoietin (Epo) ${ }^{90}$ is mediated by p38. ERK1-2, p38 and JNK-2 were rapidly and transiently activated by Epo. However, only SB203580 but not PD98059 could suppress Epo-induced differentiation. SB203580 also prevented cyclosporinA-induced 
haemoglobin synthesis in K562 cells, while another MEK inhibitor U0126, enhanced it, suggesting that activation of p38 and inactivation of ERK are involved in erythroid differentiation ${ }^{89}$.

\section{p38 IN PROLIFERATION}

When referring to the regulation of proliferative processes, the general rule would be that there is no general rule, as p38 exhibits the same phenomenology previously described for differentiation and apoptosis. It can exert either a positive or a negative control depending on the cell type and the mitogenic stimulus in question. There is now ample evidence to assert that p38 activation favours proliferation in several cellular systems.

Using specific inhibitors for MEK and p38, it was demonstrated that both ERK and p38 are critically involved in the transduction of a proliferative signal and cooperate in G-CSF-induced cell proliferation in hemopoietic cells ${ }^{93}$. Factors that promote T cell proliferation IL-2 and IL-7, activate both JNK and p38. Inhibition of p38 with pyrinidyl imidazoles correlated with suppression of IL-2/7-driven $\mathrm{T}$ cell proliferation $^{94}$. In both cases, the proliferative effect of p38 activation was mediated by its substrate MAРКАР-K2. There is also evidence that $\mathrm{p} 38$ can be activated by other hemopoietic growth factors, including Steel locus factor, colony stimulating factor-1, granulocyte/macrophage-colony stimulating factor, interferons and interleukin- $3^{95}$.

In Swiss 3T3 fibroblasts and PC12 cells, FGF-2 activates ERK with similar kinetics. By contrast, in PC12 cells p38 is activated weakly and transiently, while a much stronger and sustained activation of p38 is seen in FGF-2-treated fibroblasts. Inhibition of ERK blocks differentiation but has little effect on proliferation. Contrarily, inhibitors of p38 block proliferation but have no effect on differentiation ${ }^{96}$.

On the other hand, and to complicate things further, p38 can behave as an antagonist of mitogenic signalling. This is best exemplified by the relationship among p38 and the components of the Ras/ERK pathway, reminiscent of the situations observed in the regulation of apoptosis though, quite expectedly, with opposed effects. In some cells like NIH3T3, p38 can be activated by Ras and this activation provides a negative feedback for Ras proliferative signalling ${ }^{97}$. In agreement, in primary human fibroblasts Ras induces premature senescence through sequential activation of the MEK-ERK pathway and the MKK3/6-p38 pathway $^{98}$. Also, ectopic expression of MEKK3 induces G1 arrest and reverses Ras-mediated transformation in NIH3T3 fibroblasts by downregulating cyclin D199. Recent reports go a bit further, suggesting that downregulation of p38 is an essential requirement for Rasinduced transformation ${ }^{100}$.
Interactions between Ras/ERK and p38 MAPKs become even more complex when the different p38 isoforms are taken into account. A new twist has been recently provided by the direct interaction between p38 and ERK MAPKs as a mechanism for regulating ERKs functions. p38 can bind to ERK and this interaction downregulates ERK phosphorylation state ${ }^{101}$. Interestingly, Mxi2, a p38 $\alpha$ splice isoform with a striking sensitivity to growth factor stimulation ${ }^{25}$ can also bind to ERK1/2, but as opposed to p38, upregulates its nuclear activity by sustaining its phosphorylation levels in the nucleus but not in the cytoplasm ${ }^{102}$. Since Mxi2 and p38 are splice variants of the same gene, this opens an attractive scenario in which, by switching the splicing taking place at the p38 locus, the signalling machinery could be programmed to up-or down-regulate ERK activity, with its subsequent alterations on the proliferative/survival signals resulting from ERK activation.

\section{p38 IN THE REGULATION OF CELL CYCLE PROGRESSION}

At this stage, it should come as no surprise that proteins with such profound effects on proliferation, differentiation and apoptosis should impinge significantly on the machinery that regulates cell cycle progression. The first evidences were obtained in CCL39 cells and in NIH3T3 fibroblasts in which p38 negatively regulated cell cycle progression in the G1/S transition, mediated by the inhibition of cyclin D1 expression. In cells expressing high levels of MKK3, a significant inhibition of mitogen-induced cyclin D1 expression was observed. Accordingly, inhibition of p38 with SB203580 augmented cyclin D1 protein levels ${ }^{103}$. Cyclin D1 seems to be one of the favoured targets for p38-mediated control but other cell cycle checkpoints are also subject to p38 regulation.

Regarding the G1/S transition, the Rho GTPase Cdc42 can inhibit cell cycle progression at G1/S through a mechanism requiring the activation of $\mathrm{p} 38^{104}$. Likewise, a constitutively active MKK6 is also capable of inducing cell cycle arrest on G1 and senescence in a p38-dependent fashion ${ }^{105}$. The growth-inhibitory effects of TGF- $\beta$ are at least partially mediated by the TАК1-MKК6-p38K pathway. In renal tubular cells promoter activities in cyclins D1 and A genes and cell cycle progression are negatively regulated by the TAK1-MКК6-p38 pathway and positively regulated by the MEK-ERK pathway ${ }^{106}$.

The G2/M checkpoint is also under the influence of p38 regulation. Indeed, recent reports indicate that regulation by p38 of the phosphorylation of the phosphatase Cdc25B is a critical step at this checkpoint $^{63}$. Another isoform p38 $\gamma$, is required for gammairradiation-induced G2 arrest. Activation of the МКК6-p38 $\gamma$ cascade is sufficient to produce a halt at 
the G2/M transition, while the expression of dominant negative MKK6 or p38 $\gamma$ allows cells to escape the DNA damage-induced G2 arrest. p38 $\gamma$ effects are mediated by $\mathrm{Cds1/Chk} 2^{107}$. In a similar fashion, in CCL39 and Rat-1 cells, MEKK3 induces cell cycle arrest at G2/M by a mechanism dependent on $\mathrm{p} 38 \alpha / \beta$ that involves the up-regulation of $\mathrm{p} 21$ and the inhibition of cyclinA/Cdk2 and cyclinB/Cdk1 ${ }^{108}$.

In the metaphase/anaphase or mitotic spindle check point p38, but not ERK or JNK, is activated when cells are arrested in $\mathrm{M}$ phase by the disruption of the spindle with nocodazole. Injection of activated p38 into cleaving Xenopus embryos induced mitotic arrest. Treatment of NIH 3T3 cells with a inhibitor of p38 compromised the spindle assembly checkpoint function, suggesting that p38 is essential in this process in somatic cell cycles ${ }^{109}$. Persistent activation of p38 blocks foetal thymocyte development at the CD25(+)CD44(-) stage, but inactivation of p38 is required for further differentiation into CD4(+)CD8(+) thymocytes. The arrest in mitosis is partially responsible for the blockade of differentiation. Highlighting that p38 is a critical regulatory element of differentiation and proliferation during the early stages of thymocyte development ${ }^{110}$. There are also studies under physiological conditions that show how p38 is activated during normal mitosis in retinal neuroblasts. The cell cycle in the proliferative zone of the retina is tightly controlled and proceeds in synchrony with interkinetic migration of the neuroblast nuclei. Mitotic profiles in the developing retina are highly enriched in phosphorylated p38. Blockade of p38 activity with SB203580 transiently arrested neuroblasts at the metaphase-anaphase transition, while prolonged p38 inhibition induced cell death. p38 inhibition also induced an aberrant mitotic profile, with polarized chromosomes. Suggesting that p38 is required for proper cell cycle progression during the metaphaseanaphase transition ${ }^{111}$.

\section{INVASION AND METASTASIS}

Once cellular transformation has taken place, a series of processes must ensue before full-blown cancer develops, namely: migration from the primary site and invasion of sorrounding tissues. Intravasation and dissemination through the vascular system. Neocolonization at distant sites and secondary, metastatic growth, that in a similar fashion to the growth of the primary tumour, also requires neovascularization. p38 is also involved in most of these processes.

Migration of miocytes induced by PDGF can be blocked by p38 inhibitors, in a process mediated by HSP27 and F-actin polimerization ${ }^{112}$. Likewise, increased migration of lung endothelial cells induced by Heregulin is p38-dependent, as SB203580 can readily inhibit the process ${ }^{113}$. Once again, a cross talk betwe- en p38 and ERK pathways seems determinant in the regulation of migration, as it is the ratio between the activities of these two kinases what dictates the migratory propensity of epithelial cells ${ }^{114}$.

Migration and subsequent invasion of sorrounding tissue requires the destruction of the extracellular matrix and underlying basal laminas enclosing the primary growth. In these processes, the secretion of proteases cocktails from the tumour cells plays an essential role. A large body of evidence point to p38 as an important regulator of protease synthesis and secretion. In malignant melanoma cells a p38 inhibitor blocked the expression of matrix-metalloproteinase (MMP-2) and reduced the invasive potential of these cells ${ }^{115}$. In squamous cell carcinoma cell lines, phorbol ester-enhanced secretion of metalloproteinase 9 (MMP-9) and in vitro invasiveness, correlated with a strong activation of $\mathrm{p} 38^{116}$. Expression of collagenases 3 (MMP-13) and 1 (MMP-1) in transformed keratinocytes are also p38-dependent (117). Apparently, the activation of p38 enhances MMP-1 and stromelysin (MMP-3) expression by stabilizing their mRNA ${ }^{118}$.

Once dissemination through the vascular system and extravasation have taken place, cancer cells may either resume growth, leading to overt metastasis, or enter a state of protracted dormancy. ERK/p38 activity ratio predicts whether the cells will proliferate or enter a state of quiescence. In breast, prostate, melanoma, and fibrosarcoma cell lines, the level of active ERK and the $\mathrm{ERK} / \mathrm{p} 38$ activity ratio predict for this behaviour in approximately $90 \%$ of the cell lines tested. Modulation of ERK/p38 activity ratio by multiple pharmacological and genetic interventions confirms that low p38/ERK ratio promotes tumor growth, whereas a high p38/ERK ratio favours proliferative arrest ${ }^{119}$.

p38 MAPKs can also be pivotal elements in the growth of primary tumours and in the metastatic process by virtue of their role as regulators of vascularization. As a proof of it, p38 has been found to be activated in response to Vascular Endothelial Growth Factor (VEGF) in endotelial cells, in which p38 activity is also required to regulate cellular migration ${ }^{120}$. Angiogenesis induced by TNF- $\alpha$ is partly mediated by ephrin A1. In endothelial cells, ephrin A1 induction can be blocked by pyridinyl imidazoles ${ }^{121}$. In a similar fashion, VEGF secretion is upregulated by IL-1 in human vascular smooth muscle cells by a mechanism involving p38 ${ }^{122}$. Lastly, the Kaposis sarcomaassociated herpesvirus G protein-coupled receptor, a potent stimulator of neovascularization and angiogenesis, upregulates VEGF expression and secretion with the participation of ERK and p38 pathways ${ }^{123}$.

\section{CONCLUSIONS AND PERSPECTIVES}

At this stage, it is undoubted that MAPKs play key role in the processes that bring about malignification. 
Thus, modulating the activities of MAPKs as a means to prevent tumoral growth and progression is now a widespread anti neoplastic strategy at its initial stages. Indeed, it is clear that the activities of MAPKs, in particular p38, are subject to regulation upon exposure to diverse classes of anti tumoral agents. With increased evidence supporting a role for MAPK signalling in antitumour drug action, p38 regulators may have an enormous potential as chemotherapeutic drugs themselves or as chemosensitizing agents. However, it is becoming clear that these responses tend to be context-dependent, and can differ enormously depending on the cellular system and conditions. The biological outcomes of p38 activation/inhibition may be completely different depending on the cell type and subtle variations when interfering with the intensity and duration of p38 signals can result in profound, unexpected and sometimes unwanted effects. Therefore modulation of p38 as an anti tumoral strategy, although theoretically promising, must be at this stage regarded with extreme caution and must always be based on a broad knowledge of the biological idiosyncrasy of the type of tumour subject to treatment.

\section{References}

1. Robinson MJ, Cobb MH. Mitogen activated protein kinase pathways. Curr Opin Cell Biol 1997; 9: 180-6.

2. Pearson G, Robinson F, Gibson TG, et al. Mitogen-Activated Protein (MAP) Kinase pathways: Regulation and physiological functions. Endocrine Revs 2001; 22: 15383.

3. Han J, Lee J, Bibbs L, Ulevitch RT. A MAP kinase targeted by endotoxin and hyperosmolarity in mammalian cells. Science 1994; 265: 808-11.

4. Lee JC, Laydon JC, McDonnel PC, et al. Identification and characterization of a novel protein kinase involved in the regulation of inflammatory cytokine biosynthesis. Nature 1994; 372: 739-46.

5. Jiang Y, Chen C, Li Z, et al. Characterization of the structure and function of a new mitogen-activated protein kinase p38b. J Biol Chem 1996; 271: 17920-6.

6. Jiang Y, Gram H, Zhao M, et al. Characterization of the structure and function of the fourth member of p38 group mitogen-activated protein kinase p38d. J Biol Chem 1997; 272: 30122-8.

7. Kumar S, McDonnel PC, Gum RJ, Hand AT, Lee JC, Young PR. Novel homologues of CSBP/p38 MAP kinase: activation, substrate specificity and sensitivity to inhibition by pyridinyl imidazoles. Biochem Biophys Res Comm 1997; 235: 533-8.

8. Mertens S, Craxton M, Goedert M. SAP kinase-3, a new member of the family of mammalian stress-activated protein kinases. FEBS lett 1996; 383: 273-6.

9. Goedert M, Cuenda A, Craxton M, Jakes R, Cohen P. Activation of the novel stress-activated protein kinase SAPK4 by cytokines and cellular stresses is mediated by SKK3 (MKK6); comparison of its substrate specificity with that of other SAP kinases. EMBO J 1997; 16: 3563-71.

10. Li Z, Jiang Y, Ulevitch RJ, Han J. The primary structure of p38 gamma: a new member of the p38 group of MAP kinases. Biochem Biophys Res Comm 1996; 228: 33440 .
11. McDonell PC, DiLella AG, Lee JC, Young PR. Localization of the human stress responsive MAP kinase-like CSAIDs binding protein (CSBP) gene to chromosome 6q21. 3/21.2. Genomics 1995; 29: 301-2.

12. Zervos AS, Faccio L, Gatto JP, Kyriakis JM, Brent R. Mxi2, a mitogen activated protein kinase that recognizes and phosphorylates Max protein. Proc Natl Acad Sci USA 1995; 92: 10531-4.

13. Sudo T, Yagasaki Y, Hama H, Watanabe N, Osada H. Exip, a new alternative splicing variant of p38alpha, can induce an earlier onset of apoptosis in HeLa cells. Biochem Biophys Res Com 2002; 291: 838-43.

14. Stein B, Yang MX, Young DB, Janknecht R, Hunter T, Murray BW, et al. p38-2 a novel Mitogen activated protein kinase with distinct properties. J Biol Chem 1997; 272: 19509-17.

15. Hazan-Halevy I, Seger R, Levy R. The requirement of both extracellular regulated kinase and p38 mitogenactivated protein kinase for stimulation of cytosolic phospholipase $A(2)$ activity by either Fc $\gamma$ RIIA o Fc$\gamma$ RIIIB in human neutrophils. A possible role for pyk2 but not for the grb-2-sos-shc complex. J Biol Chem 2000; 275: 12416-23.

16. McLauhlin MM, Kumar S, McDonell PC, et al. Identification of MAPKAP kinase 3, a novel substrate of CSBP/p38 MAP kinase. J Biol Chem 1996; 271: 848892.

17. Deak M, Clifton AD, Lucocq LM, Alessi DR. Mitogen and stress activated protein kinase 1 (MSK1) is directly activated by MAPK and SAPK2/p38, and may mediate activation of CREB. EMBO J 1998; 17: 4426-41.

18. Fukunaga R, Hunter R. MNK1, a new MAP kinase-activated protein kinase, isolated by a novel expression screening method for identifying protein kinase substrates. ЕМBO J 1997; 16: 1921-33.

19. New L, Jiang Y, Zhao M, et al. PRAK, a novel protein kinase regulated by the p38 MAPK. ЕМBO J 1998; 17: 3372-84.

20. Price MA, Rogers AE, Treisman R. Comparative analysis of the ternary complex factors Elk-1, Sap-1 and Sap2. EMBO J 1995; 14: 2589-601.

21. Gupta S, Campbell D, Dérijard B, Davis RJ. Transcription factor ATF-2 regulation by the JNK signal transduction pathway. Science 1995; 267: 389-93.

22. Han J, Jiang Y, Li Z, Kravchenco VV, Ulevitch RJ. Activation of the transcription factor MEF2C by the p38 MAPK in inflammation. Nature 1997; 386: 296-9.

23. Wang XZ, Roy D. Stress-induced phosphorylation and activation of the transcription factor CHOP (GADD 153) by p38. Science 1996; 272: 1347-9.

24. Faccio L, Chen A, Fusco C, Martinotti S, Bonventre JV, Zervos AS. Mxi2 a splice variant of p38 stress-activated kinase is a distal nephron protein regulated with kidney ischemia. Am J Physiol Cell Physiol 2000; 278: 78191.

25. Sanz V, Arozarena I, Crespo P. Distinct carboxy-termini confer divergent characteristics to the mitogen-activated protein kinase p38alpha and its splice isoform Mxi2. FEBS Lett 2000; 474:169-74.

26. Lechner C, Zahalka MA, Giot JF, Moller NP, Ullrich A. ERK6, a mitogen-activated protein kinase involved in C2C12 myoblast differentiation. Proc Natl Acad Sci USA 1996; 93:4355-9.

27. Tibbles LA, Woodgett JR. The stress activated protein kinase pathways. Cell Mol Life Sci 1999; 55: 1230-54.

28. Zohn IE, Symons M, Chrzanowska-Wodnicka M, Westwick JK, Der CJ. Mas oncogene signalling and transformation require the small GTP-binding protein Rac. Mol Cell Biol 1998; 18: 1225-35. 
29. Bais C, Santomasso B, Coso O, Arvanitakis L, Raaka EG, Gutkind JS. G-protein coupled receptor of Kaposi's sarcoma-associated herpesvirus is a viral oncogene and angiogenesis activator. Nature 1998; 391: 86-9.

30. Greenberg AK, Basu S, Hu J, et al. Selective p38 activation in human non-small cell lung cancer. Am J Respir Cell Mol Biol 2002; 26:558-64.

31. Salh B, Marotta A, Wagey R, Sayed M, Pelech S. Dysregulation of phosphatidylinositol 3-kinase and downstream effectors in human breast cancer. Int J Cancer 2002; 98:148-54.

32. Uzgare AR, Kaplan PJ, Greenberg NM. Differential expression and/or activation of P38MAPK, erk1/2, and jnk during the initiation and progression of prostate cancer. Prostate 2003; 55:128-39.

33. Hideshima T, Akiyama M, Hayashi T, et al. Targeting p38 MAPK inhibits multiple myeloma cell growth in the bone marrow milieu. Blood 2003; 101: 703-5.

34. Wong AS, Kim SO, Leung PC, Auersperg N, Pelech SL. Profiling of protein kinases in the neoplastic transformation of human ovarian surface epithelium. Gynecol Oncol $2001 ; 82: 305-11$.

35. Schmitz I, Kirchhoff S, Krammer PH. Regulation of death receptor-mediated apoptosis pathways. Int J Biochem Cell Biol 2000; 32: 1123-36.

36. Johnson JL, Gardner AM, Diener KM, et al. Signal transduction pathways regulated by mitogen-activated/extracellular response kinase kinase kinase induce cell death. J Biol Chem 1996; 271: 3229-37.

37. Chuang TH, Hahn KM, Lee JD, Danley DE, Bokoch GM. The small GTPase Cdc42 initiates an apoptotic signaling pathway in Jurkat T lymphocytes. Mol Biol Cell 1997; 8:1687-98.

38. Ichijo H, Nishida E, Irie K, et al. Induction of apoptosis by ASK-1 a mammalian MAPKKK that activates SAPK/JNK and p38 signaling pathways. Science 1997; 275: 90-4.

39. Brenner B, Koppenhoefer U, Weinstock C, Linderkamp O, Lang F, Gulbins E. Fas-or ceramide-induced apoptosis is mediated by a Rac- 1 regulated activation of Jun N-terminal kinase/p38 kinases and GADD153. J Biol Chem 1997; 272: 22173-81.

40. Gabai VL, Meriin AB, Mosser DD, et al. Hsp70 prevents activation of stress kinases. A novel pathway of cellular thermotolerance. J Biol Chem 1997; 272: 18033-7.

41. Heidenreich KA, Kummer JL. Inhibition of p38 mitogen-activated protein kinase by insulin in cultured fetal neurons. J Biol Chem 1996; 271: 9891-4.

42. Franklin CC, Srikanth S, Kraft AS. Conditional expression of mitogen activated protein kinase phosphatase1, MKP-1, is cytoprotective against UV induced apoptosis. Proc Natl Acad Sci USA 1998 ; 270: 49-53.

43. Chen HH, Zhao S, Song JG. TGF-beta1 suppresses apoptosis via differential regulation of MAP kinases and ceramide production. Cell Death Differ 2003; 10: 516-27.

44. Zanke BW, Boudreau K, Rubie E, et al. The stress-activated protein kinase pathway mediates cell death following injury induced by cis-platinum, UV irradiation or heat. Curr Biol 1996; 6: 606-13.

45. Le-Niculescu H, Bonfonco E, Kasuya Y, Claret FX, Green DR, Karin M. Withdrawal of survival factors results in activation of the JNK pathway in neuronal cells leading to Fas ligand induction and cell death. Mol Cell Biol 1999; 19: 751-63.

46. Zechner D, Craig R, Hanford DS, McDonough PM, Sabbadini RA, Glembotski CC. MKK6 activates myocardial cell NF-kappaB and inhibits apoptosis in a p38-dependent manner. J Biol Chem 1998; 273: 8232-9.
47. Roulston A, Reinhard C, Amiri P, Williams LT. Early activation of c-Jun N-terminal kinase and p38 kinase regulate cell survival in response to tumor necrosis factor alpha. J Biol Chem 1998; 273: 10232-9.

48. Mao Z, Bonni A, Xia F, Nadal-Vicens M, Greenberg ME. Neuronal activity-dependent cell survival mediated by transcription factor MEF2C. Science 1999; 286: 785-90.

49. Nemoto S, Sheng Z, Lin A. Opposing effects of Jun kinase and p38 mitogen activated protein kinases on cardiomyocyte hypertrophy. Mol Cell Biol 1998; 18: 3518-26.

50. Guo YL, Kang B, Han J, Williamson JR. p38beta MAP kinase protects rat mesangial cells from TNF-alpha-induced apoptosis. J Cell Biochem 2001; 82: 556-65.

51. Xia Z, Dickens M, Raingeaud J, Davis RJ, Greenberg ME. Opposing effects of ERK and JNK-p38 kinases on apoptosis. Science 1995; 270: 1326-31.

52. Marshall CJ. Specificity of receptor tyrosine kinase signaling: transient versus sustained extracellular signalregulated kinase activation. Cell 1995; 80:179-85.

53. York RD, Yao H, Dillon T, et al. Rap1 mediates sustained MAP kinase activation induced by nerve growth factor. Nature1998; 392: 622-6.

54. Kanamoto T, Mota M, Takeda K, et al. Role of apoptosis signal-regulating kinase in regulation of the c-Jun Nterminal kinase pathway and apoptosis in sympathetic neurons. Mol Cell Biol 2000; 20: 196-204.

55. Takeda K, Hatai T, Hamazaki TS, Nishitoh H, Saitoh M, Ichijo H. Apoptosis signal-regulating kinase 1 (ASK1) induces neuronal differentiation and survival of PC12 cells. J Biol Chem 2000; 275: 9805-13.

56. Roulston A, Reinhard C, Amiri P, Williams LT. Early activation of c-Jun N-terminal kinase and p38 kinase regulate cell survival in response to tumor necrosis factor $\alpha$. J Biol Chem 1998; 273: 10232-9.

57. Nagata Y, Todokoro K. Requirement of activation of JNK and p38 for environmental stress-induced erythroid differentiation and apoptosis and of inhibition of ERK for apoptosis. Blood 1999; 94: 853-63.

58. Pepper C, Thomas A, Fegan C, Hoy T, Bentley P. Flavopiridol induces apoptosis in B-cell chronic lymphocytic leukaemia cells through a p38 and ERK MAP kinase-dependent mechanism. Leuk Lymphoma 2003; 44: 337-42.

59. Iwama K, Nakajo S, Aiuchi T, Nakaya K. Apoptosis induced by arsenic trioxide in leukemia U937 cells is dependent on activation of p38, inactivation of ERK and the $\mathrm{Ca} 2+-$ dependent production of superoxide. Int $\mathrm{J}$ Cancer 2001; 92: 518-26.

60. Seidman R, Gitelman I, Sagi O, Horwitz SB, Wolfson M. The role of ERK 1/2 and p38 MAP-kinase pathways in taxol-induced apoptosis in human ovarian carcinoma cells. Exp Cell Res 2001; 268: 84-92.

61. Bacus SS, Gudkov AV, Lowe M, et al. Taxol-induced apoptosis depends on MAP kinase pathways (ERK and p38) and is independent of p53. Oncogene 2001; 20: 147-55.

62. Kultz D, Madhany S, Burg MB. Hyperosmolarity causes growth arrest of murine kidney cells. Induction of GADD45 and GADD153 by osmosensing viastress-activated protein kinase 2. J Biol Chem 1998;273:1364551.

63. Bulavin DV, Higashimoto Y, Popoff IJ, Gaarde WA, Basrur V, Potapova O, et al. Initiation of a G2/M checkpoint after ultraviolet radiation requires p38 kinase. Nature 2001; 411(6833):102-7.

64. Sánchez-Prieto R, Rojas JM, Taya Y, Gutkind JS. A role for the p38 mitogen-activated protein kinase pathway in the transcriptional activation of p53 on genotoxic stress by chemotherapeutic agents. Cancer Res 2000; 60: 2464-72. 
65. Kim SJ, Hwang SG, Shin DY, Kang SS, Chun JS. p38 kinase regulates nitric oxide-induced apoptosis of articular chondrocytes by accumulating p53 via NFkappa Bdependent transcription and stabilization by serine 15 phosphorylation. J Biol Chem 2002; 277: 33501-8.

66. Chouinard N, Valerie K, Rouabhia M, Huot J. UVB-mediated activation of $\mathrm{p} 38$ mitogen-activated protein kinase enhances resistance of normal human keratinocytes to apoptosis by stabilizing cytoplasmic p53. Biochem J 2002; 365: 133-45.

67. Takekawa M, Adachi M, Nakahata A, et al. p53-inducible wip1 phosphatase mediates a negative feedback regulation of p38 MAPK-p53 signaling in response to UV radiation. EMBO J 2000; 19:6517-26.

68. Bulavin DV, Demidov ON, Saito S, et al. Amplification of PPM1D in human tumors abrogates p53 tumor-suppressor activity. Nat Genet 2002;31: 210-5.

69. Li J, Yang Y, Peng Y, et al. Oncogenic properties of PPM1D located within a breast cancer amplification epicenter at $617 \mathrm{q} 23$. Nat Genet 2002; 3:133-4.

71. Kim BS, Yoon KH, Oh HM, et al. Involvement of p38 MAP kinase during iron chelator-mediated apoptotic cell death. Cell Immunol 2002; 220: 96-106.

72. Sarker KP, Biswas KK, Yamakuchi M, et al. ASK1p38 MAPK/JNK signaling cascade mediates anandamide-induced PC12 cell death. J Neurochem 2003; 85: 50-61.

73. Lee MW, Park SC, Yang YG, et al. The involvement of reactive oxygen species (ROS) and p38 mitogen-activated protein (MAP) kinase in TRAIL/Apo2L-induced apoptosis. FEBS Lett 2002; 512: 313-8.

74. Luo C, Xu R, Yang Z. Signal transduction pathway of nitric oxide inducing PC12 cell death. Chin J Traumatol $2001 ; 4: 86-8$.

75. Hur J, Kim SY, Kim H, Cha S, Lee MS, Suk K. Induction of caspase-11 by inflammatory stimuli in rat astrocytes: lipopolysaccharide induction through p38 mitogen-activated protein kinase pathway. FEBS Lett 2001; 507:157-62.

76. Nath R, McGinnis K, Dutta S, Shivers B, Wang KK. Inhibition of p38 kinase mimics survival signal-linked protection against apoptosis in rat cerebellar granule neurons. Cell Mol Biol Lett 2001; 6: 173-84.

77. Engelman JA, Berg AH, Lewis RY, Lisanti MP, Scherer PE. Constitutively active mitogen-activated protein kinase kinase 6 or salicylate induces spontaneous 3T3L1 adipogenesis. J Biol Chem 1999; 274: 35630-8.

78. Engelman JA, Lisanti MP, Scherer PE. Specific inhibitors of p38 mitogen-activated protein kinase block 3T3L1 adipogenesis. J Biol Chem 1998; 273: 32111-20.

79. Hata K, Nishimura R, Ikeda F, et al. Diffential roles of Smad1 and p38 MAPK in regulation of peroxisome proliferator activating receptor gamma during bone morhogenetic protein-2-induced apoptosis. Mol Biol Cell 2003; 14: 545-55.

80. Cuenda A, Cohen P. Stress-activated protein kinase2/p38 and rapamycin sensitive pathway are required for C2C12 myogenesis. J Biol Chem 1999; 274: 4341-6.

81. Zetser A, Gredinger E, Bengal E. p38 MAPK pathway promotes skeletal muscle differentiation. Participation of the MEF2C transcription factor. J Biol Chem 1999; 274: 5193-200.

82. Lee J, Hong F, Kwon S, et al. Activation of p38 MAPK induces cell cycle arrest via inhibition of Raf/ERK pathway during muscle differentiation. Biochem Biophys Res Com 2002; 298: 765-71.

83. Morooka T, Nishida E. Requirement of p38 mitogen-activated protein kinase for neuronal differentiation in PC12 cells. J Biol Chem 1998; 272: 24285-8.
84. Morooka T, Nishida E. Requirement of p38 mitogen-activated protein kinase for neuronal differentiation in PC12 cells. J Biol Chem 1998; 273: 24285-8.

85. Nebreda AR, Porras A. p38 MAP kinases: beyond the stress response. Trends Biochem Sci 2000; 25: 257-60.

86. Hu Y, Chan E, Wang SX, Li B. Activation of p38 MAPK is required for osteoblast differentiation. Endocrinology 2003; 144: 2068-74.

87. Nakamura K, Shirai T, Morishita S, Uchida S, SaekiMiura K, Makishima F. p38 Mitogen-activated protein kinase functionally contributes to chondrogenesis induced by growth/differentiation factor-5 in ATDC5 cells. Exp Cell Res 1999; 250: 351-63.

88. Lim YB, Kang SS, An WG, Lee YS, Chun JS, Sonn JK. Chondrogenesis induced by actin cytoskeleton disruption is regulated via PKC-dependent p38 MAPK signaling. J Cell Biochem 2003; 88: 713-8.

89. Sawafuji K, Miyakawa Y, Kizaki M, Ijeda Y. Cyclosporin A induces erythroid differentiation of K562 cells through p38 MAPK and ERK pathways. Am J Hematol 2003; 72: 67-9.

90. Nagata Y, Takahaxhi N, Davis RJ, Todokoro K. Activation of p38 MAPK and JNK but nor ERK is required for erythropoietin-induced differentiation. Blood 1998; 92: 1859-69.

91. McKinsey TA, Olson EN. Cardiac hypertrophy: sorting out the circuitry. Curr Opin Genet Dev 1999; 9: 267-74.

92. Wang Y, Huang S, Sah VP, et al. Cardiac muscle cell hypertrophy and apoptosis induced by distinct members of the p38 mitogen activated protein kinase family. J Biol Chem 1999; 273: 161-8.

93. Rausch O, Marshall CJ. Cooperation of p38 and extracellular signal-regulated kinase mitogen-activated protein kinase pathways during granulocyte colony stimulating factor induced hemopoietic cell proliferation. J Biol Chem 1999; 274: 4096-105.

94. Crawley JB, Rawlinson L, Lali FV, Page TH, Saklatvala J, Foxwell BM. T cell proliferation in response to interleukins 2 and 7 requires p38MAP kinase activation. J Biol Chem 1997; 272: 15023-7.

95. Foltz IN, Lee JC, Young PR, Schrader JW. Hemopoietic growth factors with the exception of interleukin-4 activate the p38 mitogen-activated protein kinase pathway. J Biol Chem 1997; 272: 3296-301.

96. Maher P. p38 Mitogen-activated protein kinase activation is required for fibroblast growth factor-2 -stimulated cell proliferation but nor differentiation. J Biol Chem 1999; 274: 17491-8.

97. Chen G, Hitom M, Han J, Stacey DW. The p38 pathway provides negative feedback for Ras proliferative signaling. J Biol Chem 2000; 27: 38973-80.

98. Wang W, Chen JX, Liao R, et al. Sequential activation of the MEK-extracellular signal-regulated kinase and MKK3/6-p38 mitogen-activated protein kinase pathways mediates oncogenic ras-induced premature senescence. Mol Cell Biol 2002; 22: 3389-403.

99. Ellinger-Zieegelbauer H, Brown K, Kelly K, Siebenlist U. Direct activation of the SAPK and ERK pathways by an inducible MEKK3 derivative. J Biol Chem 1999; 272: 2668-74.

100. Pruitt K, Pruitt WM, Bilter GK, Westwick JK, Der CJ. Raf-independent deregulation of p38 and JNK mitogen-activated protein kinases are critical for Ras transformation. J Biol Chem 2002; 277: 31808-17.

101. Zhang H, Shi X, Hampong M, Blanis L, Pelech S. Stressinduced inhibition of ERK1 and ERK2 by direct interaction with p38 MAP kinase. J Biol Chem 2001; 276: 6905-8.

102. Sanz-Moreno V, Casar B, Crespo P. p38alpha Isoform Mxi2 Binds to Extracellular Signal-Regulated Kinase 1 
and 2 Mitogen-Activated Protein Kinase and Regulates Its Nuclear Activity by Sustaining Its Phosphorylation Levels. Mol Cell Biol 2003; 23: 3079- 90.

103. Lavoie JN, L' Allemain G, Brunet A, Muller R, Pouyssegur J. Cyclin D1 expression is regulated by the p38/MAPK pathway. J Biol Chem 1996; 34: 20608-16.

104. Molnar A, Theodoras AM, Zon LI, Kyriakis JM. Cdc42Hs, but not Rac1, inhibits serum-stimulated cell cycle progression at G1/S through a mechanism requiring p38/RK. J Biol Chem 1997; 272: 13229-35.

105. Haq R, Brenton JD, Takahashi M, et al. Constitutive p38HOG mitogen-activated protein kinase activation induces permanent cell cycle arrest and senescence. Cancer Res 2002; 62: 7380-6.

106. Terada Y, Nakashima O, Inoshita S, Kuwahara M, Sasaki S, Marumo F. TGF-beta-activating kinase-1 inhibits cell cycle and expression of cyclin D1 and A in LLCPK1 cells. Kidney Int 1999; 56:1378-90.

107. Wang X, McGowan CH, Zhao M, et al. Involvement of the MKK6-p38gamma cascade in gamma-radiationinduced cell cycle arrest. Mol Cell Biol 2000; 20: 454352 .

108. Garner AP, Weston CR, Todd DE, Balmanno K, Cook SJ. Delta MEKK3:ER* activation induces a p38 alpha/beta 2-dependent cell cycle arrest at the G2 checkpoint. Oncogene 2002; 21: 8089-104.

109. Takenaka K, Moriguchi T, Nishida E. Activation of the protein kinase p38 in the spindle assembly checkpoint and mitotic arrest. Science 1998; 280: 599-602.

110. Diehl NL, Enslen H, Fortner KA, et al. Activation of the p38 mitogen-activated protein kinase pathway arrests cell cycle progression and differentiation of immature thymocytes in vivo. J Exp Med 2000; 191: 321-34.

111. Campos CB, Bedard PA, Linden R. Activation of p38 mitogen-activated protein kinase during normal mitosis in the developing retina. Neuroscience 2002;112: 583-91.

112. Hedges JC, Dechert MA, Yamboliev IA, et al. A role for p38(MAPK)/HSP27 pathway in smooth muscle cell migration. J Biol Chem 1999; 274: 24211-9.

113. Xiong S, Grijalva R, Zhang L, et al. Up-regulation of vascular endothelial growth factor in breast cancer cells by the heregulin-beta1-activated p38 signaling pathway enhances endothelial cell migration. Cancer Res 2001; 61: 1727-32.
114. Sharma GD, He J, Bazan HE. p38 and ERK1/2 coordinate cellular migration and proliferation in epithelial wound healing: evidence of cross-talk activation between MAP-kinase cascades. [In press] J Biol Chem 2003.

115. Denkert C, Siegert A, Leclere A, Turzynski A, Hauptmann S. An inhibitor of stress-activated MAP-kinases reduces invasion and MMP-2 expression of malignant melanoma cells. Clin Exp Metastasis 2002;19: 79-85.

116. Simon C, Goepfert H, Boyd D. Inhibition of the p38 mitogen-activated protein kinase by SB 203580 blocks PMA-induced Mr 92,000 type IV collagenase secretion and in vitro invasion. Cancer Res 1998; 58: 1135-9.

117. Johansson N, Ala-aho R, Uitto V, et al. Expression of collagenase-3 (MMP-13) and collagenase-1 (MMP-1) by transformed keratinocytes is dependent on the activity of p38 mitogen-activated protein kinase. J Cell Sci 2000; 113: 227-35.

118. Reunanen N, Li SP, Ahonen M, Foschi M, Han J, Kahari VM. Activation of p38 alpha MAPK enhances collagenase-1 (matrix metalloproteinase [MMP]-1) and stromelysin-1 [MMP-3] expression by mRNA stabilization. J Biol Chem 2002; 277: 32360-8.

119. Aguirre-Ghiso JA, Estrada Y, Liu D, Ossowski L. ERK(MAPK) activity as a determinant of tumor growth and dormancy; regulation by p38(SAPK). Cancer Res $2003 ; 63 ; 1684-95$

120. Rousseau S, Houle F, Landry J, Huot J. p38 MAP kinase activation by vascular endothelial growth factor mediates actin reorganization and cell migration in human endothelial cells. Oncogene 1997; 15: 2169-77.

121. Cheng N, Chen J. Tumor necrosis factor-alpha induction of endothelial ephrin A1 expression is mediated by a p38 MAPK- and SAPK/JNK-dependent but nuclear factor-kappa B-independent mechanism. J Biol Chem 2001; 276:13771-7.

122. Jung YD, Liu W, Reinmuth N, et al. Vascular endothelial growth factor is upregulated by interleukin-1 beta in human vascular smooth muscle cells via the P38 mitogen-activated protein kinase pathway. Angiogenesis 2001 ; 4:155-62.

123. Montaner S, Sodhi A, Pece S, Mesri EA, Gutkind JS. The Kaposi's sarcoma-associated herpesvirus G proteincoupled receptor promotes endothelial cell survival through the activation of Akt/protein kinase B. Cancer Res 2001; 61: 2641-8. 